\title{
EFFECT OF REACTION TIME AND SODIUM HYDROXIDE CONCENTRATION ON DELIGNIFICATION AND ENZYMATIC HYDROLYSIS OF BREWER'S SPENT GRAIN FROM TWO BRAZILIAN BREWERS
}

\author{
CARLA LOBO GOMES, "ELIZABETH GONÇALVES, * \\ CARLOS ALBERTO GALEANO SUAREZ, DASCIANA DE SOUSA RODRIGUES ${ }^{* *}$ and \\ INTI CAVALCANTI MONTANO* \\ *Federal University of Goiás, Chemistry Institute, \\ Postgraduate Program in Chemical Engineering, Goiânia/GO, Brazil \\ ${ }^{* *}$ Embrapa Agroenergia, Brasília/DF, Brasil \\ $\bowtie$ Corresponding author: I. C. Montano,inti@ufg.br
}

Received April 8, 2020

\begin{abstract}
Brazil, being one of the main beer producers, generates brewer's spent grain as a main by-product of this industry, which is mainly composed of cellulose, hemicelluloses, lignin and extractives. The alkaline pretreatment of brewer's spent grain received from two breweries is studied in this work, namely breweries Imperial (B1) and Colombina (B2). Factorial design $\left(2^{2}\right)$ was realized with three experiments at the central point: contact time $(30,60,90 \mathrm{~min})$ and $\mathrm{NaOH}$ concentration $(4 \%, 6 \%, 8 \%)$. It was found that the presence of extractives causes interference in the characterization of the material. The delignification process allowed obtaining materials with lower lignin percentages when higher $\mathrm{NaOH}$ concentrations were used, reaching percentages of lignin loss with values between $85-95 \%$, in both materials, but for these conditions, the losses of cellulose were considerable - of 35-43\%. Enzymatic hydrolysis of the pretreated materials achieved conversions greater than $70 \%$, emphasizing that the greatest conversions were obtained with material B1, where almost the whole cellulose was hydrolyzed.
\end{abstract}

Keywords: lignocellulosic material, brewer's spent grain, alkaline pretreatment, delignification, enzymatic hydrolysis

\section{INTRODUCTION}

Brewer's spent grain (BSG) is the lignocellulosic residue obtained in the first filtration in the beer production process. ${ }^{1-3}$ This residue represents about $85 \%$ of the total of byproducts generated in the brewing industry. ${ }^{4}$ It is a lignocellulosic material rich in fiber and protein, containing approximately $17 \%$ cellulose, $28 \%$ hemicelluloses and $28 \%$ lignin. The relative composition of each of the polymers can vary significantly according to the manufacturing and adding processes of adjunct brewers. ${ }^{5}$ Cellulose is a vegetable polysaccharide highly abundant on earth, consisting of numerous glucose units. To have access to this glucose by the biochemical route, it is necessary to remove the lignin from the material, since the process is affected by the unproductive adsorption of the enzyme (in hydrolysis), especially onto lignin.

Thus, efficient pretreatments are required to disrupt the matrix, increasing the surface area and porosity of the cellulosic material and thus allowing the release of carbohydrates associated with the lignin, increasing enzymatic digestibility. ${ }^{6}$ The goals of pretreatment are basically to remove lignin and hemicelluloses; as well as to reduce the crystallinity of cellulose and increase the porosity of materials. To be considered effective, a pretreatment must: (1) improve sugar formation or the ability to subsequently form sugars by enzymatic hydrolysis; (2) prevent carbohydrate degradation or loss; (3) prevent formation of inhibitory byproducts for subsequent hydrolysis processes and fermentation. ${ }^{7}$

Alkaline pretreatment digests lignin and makes holocellulose accessible for hydrolysis. Usually, sodium, potassium, calcium and ammonium hydroxides are used in this process. ${ }^{8}$ Studies have confirmed that the $\mathrm{NaOH}$ solution was efficient in dissolving lignin, causing lignocellulosic biomass 
to swell, leading to an increase in internal surface area under relatively mild conditions, and improving enzymatic hydrolysis of lignocellulosic biomass. $^{9}$ Park and $\mathrm{Kim}^{10}$ used a 1:10 solid to liquid ratio for alkaline pretreatment of rice straw and barley, and showed how the delignification of biomass increased enzymatic digestibility and how the reaction is controlled mainly by the structure of the alkyl aryl linkages in lignin, which is not sensitive to $[\mathrm{OH}]$, as long as the $\mathrm{pH}$ is greater than 10 . Padilha et al. ${ }^{11}$ proposed an alternative methodology for the manufacture of value-added products from green coconut fiber. Using hydrothermal and alkaline pretreatments with a solid-liquid ratio of 1:10, they were able to use the solid fraction to obtain cellulosic ethanol by simultaneous saccharification and fermentation (SSF) and biosorbent to remove textile dyes. Another study reported on the alkaline pretreatment of poplar for the extraction of xylan; this biomass contains wood lignocellulose, a material considered the most recalcitrant to enzymatic hydrolysis, mainly because of the highly lignified structure of poplar wood and the nature of the lignin component. The research showed that the best conditions for extracting xylan from poplar wood by $\mathrm{NaOH}$ were to use a $10 \%$ mass fraction of caustic soda, a solid-liquid ratio of $1: 10$ and a temperature of $120^{\circ} \mathrm{C}$ for $3 \mathrm{~h}$. The sugar yield can reach up to a little more than $20 \%$ and the effect of the four factors had a significant influence on the extraction yield, among which, the solid-liquid ratio was the least significant one. ${ }^{12}$

After the pretreatment of the lignocellulosic material, it is subjected to the hydrolysis phase, which can be performed by the action of acids or cellulolytic enzymes. Enzymatic hydrolysis is a process known and studied for presenting reaction specificity, absence of secondary reactions (which would lead to loss of yield), absence of formation of secondary products (fermentation inhibitors) and reaction under mild conditions that do not require high pressures and temperatures or corrosive environments for equipment. ${ }^{13}$

In this context, in the present work, (i) the characterization of BSG from two breweries from the Central West Region of Brazil was carried out, (ii) the actual cellulose, hemicelluloses and lignin contents of the in natura material were determined, (iii) pretreatments were subsequently carried out in order to separate the cellulose, hemicelluloses and lignin fractions and to find the optimum conditions for material delignification and (iv) the relation of yields in the enzymatic hydrolysis process was calculated.

\section{EXPERIMENTAL \\ Materials and methods}

The feedstock, brewer's spent grain, to be used in the experiments was donated by the Imperial brewery, located in Trindade, Goiás - Brazil (B1) and the Colombina brewery, located in Aparecida de Goiânia, Goiás - Brazil (B2).

\section{Chemical characterization of brewer's spent grain}

Chemical composition analyses were performed for brewer's spent grain before and after each pretreatment. The methodology employed was developed by Sluiter et $a l^{14-16}$ and validated by Gouveia et al. ${ }^{17}$

\section{Procedure for chemical characterization of dry material}

The determination of structural carbohydrates, lignin, ashes and extractives was performed according to NREL (National Renewable Energy Laboratory) procedures. ${ }^{15,16}$

Initially, empty filtering crucibles were oven-dried at $105{ }^{\circ} \mathrm{C}$ for 24 hours. Dry bagasse $(0.3 \mathrm{~g})$ and $3 \mathrm{~mL}$ of $72 \%(\mathrm{v} / \mathrm{v})$ sulfuric acid were introduced into pressure tubes, which were placed in a water bath at 30 ${ }^{\circ} \mathrm{C}$ for 60 minutes and constantly mixed. After this period, $84 \mathrm{~mL}$ of ultrapure water was added to the tubes, and they were autoclaved at $121{ }^{\circ} \mathrm{C}$ and 1 atm for 60 minutes. Hydrolyzed samples were filtered in tared crucibles; the hydrolyzed liquid was used for analysis in HPLC (high-performance liquid chromatography) for carbohydrate determination; and a spectrophotometer was used for determining soluble lignin. The solid residue was used for the determination of (1) acid insoluble lignin content and (2) acid insoluble ash content.

\section{Determination of soluble lignin}

The hydrolyzed liquids collected were analyzed by a visible UV spectrophotometer and absorbances were read at $240 \mathrm{~nm}$ wavelength. Equation (1) was used to determine the concentration of soluble lignin in the hydrolyzate:

$\% A S L=\frac{U V_{a b s} \times \text { Volume }_{\text {filtate }} \times \text { Dilution }}{\varepsilon \times \text { ODW sample } \times \text { Pathlength }} \times 100$

where $U V_{a b s}$ is UV-Visible mean absorption at the

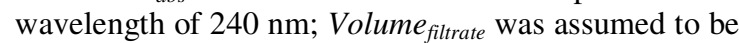

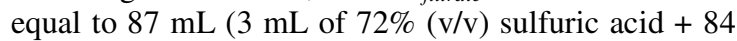
$\mathrm{mL}$ of ultrapure water); $\varepsilon$ is biomass absorptivity at specific wavelength; $O D W$ is the weight of the dry sample in milligrams, and Pathlength - the pathlength of the UV-Vis cell in $\mathrm{cm}$. 
Lignocellulose

\section{Ash determination and insoluble lignin}

The filtering crucibles containing the remaining solid after acid hydrolysis were oven-dried at $105{ }^{\circ} \mathrm{C}$ for 24 hours to constant weight for acid insoluble residue (AIR, ash and lignin) determination. Afterwards, the crucibles were placed in a muffle previously programmed for ash determination. Equations (2) and (3) were used to calculate the ash content and the percentage of insoluble lignin. ${ }^{15}$

$$
\begin{aligned}
& \% \text { Ash content }=\frac{M_{c 2}-M_{c 3}}{M_{c 2}-M_{c 1}} \times 100 \\
& \% \text { Insoluble lignin }=\frac{\left(M_{c 2}-M_{c 1}\right)-\left(M_{c 3}-M_{c 1}\right)}{M S} \times 100
\end{aligned}
$$

where Weight crucible $_{\text {is }}$ is empty crucible mass (g);

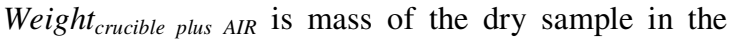
oven together with the crucible $(\mathrm{g})$; Weight crucible plus ash $_{\text {. }}$ is a sample after passage through the muffle along with the crucible $(\mathrm{g}) ; O D W_{\text {sample }}$ is initial sample dry mass (g).

\section{Extractives determination}

For in natura brewer's spent grain, the extractives content was determined based on NREL procedures. ${ }^{15}$ Thus, $10 \mathrm{~g}$ bagasse samples previously ground and dried in extraction cartridges were placed for extraction into a Soxhlet apparatus, using $200 \mathrm{~mL}$ of $99 \%$ ethyl alcohol, along with $200 \mathrm{~mL}$ of distilled water. Extraction ends when the solvent around the extraction cartridge becomes colorless. The cartridges were dried in an oven at $105{ }^{\circ} \mathrm{C}$ to constant mass. The quantification of the extractives content is described in Equation (4):

$\%$ Extractives $=\frac{M_{b}-M_{f}}{M_{b}} \times 100$

where $M_{b}$ is dry bagasse mass $(\mathrm{g}) ; M_{f}$ is extractives free bagasse mass $(\mathrm{g})$.

\section{Protein determination}

An elemental analyzer was used for the determination of carbon, hydrogen, nitrogen, sulfur and oxygen contents in organic compounds and their presence in any inorganic compound. The pretreated biomass was ground and sieved and the particles of 80 mesh size were used in protein determination. The samples need to be ground because very large particles are not digested correctly during the analysis, and consequently, the amount of nitrogen is underestimated because of the possible heterogeneity of the sample. For this reason, the milling continues until the total passage of the biomass through the 80 mesh sieve, ensuring the representativeness of the sample. For CHN mode operation, Acetanilide (BDH - Organic Analytical Standard) was used as a standard for calibration. The values were obtained as percentage of nitrogen of the sample. The protein percentage was calculated with Equation (5):

$$
\% \text { Proteins }=\frac{\frac{\% \text { Nitrogen } \times M_{a}}{100} \times 6.25}{M_{a}} \times 100
$$

where $M_{a}$ is the mass of the inserted sample.

\section{Determination of carbohydrates, organic acids, and inhibitors}

Aliquots set aside for the determination of structural carbohydrates, organic acids and inhibitors were first centrifuged at $14000 \mathrm{rpm}$ for 10 minutes to separate any residual solid particles from filtration. 0.7 $\mathrm{mL}$ samples were placed in glass vials and analyzed on HPLC under the following conditions: Aminex HPX.87 H column with pre-column, RID detector, $0.01 \mathrm{~mL}$ injection volume, $0.6 \mathrm{~mL} /$ minute mobile phase, column and detector temperature of $45{ }^{\circ} \mathrm{C}$ and run time of 60 minutes.

\section{Chemical characterization of black liquor}

The xylose monomers and glucose oligomers present in the liquor collected after the pretreatment were identified by the HPLC method. The $\mathrm{pH}$ of the black liquor was corrected to a range between 2 and 5 (ideal range for acid characterization of this material). $5 \mathrm{~mL}$ of each liquor was added to $0.174 \mathrm{~mL}$ of $72 \%$ (v/v) sulfuric acid and autoclaved at $1 \mathrm{~atm} / 121{ }^{\circ} \mathrm{C}$ in pressure tubes for 1 hour. The content was centrifuged for 5 minutes at $14000 \mathrm{rpm}$. The collected supernatant was taken to an oven at $105{ }^{\circ} \mathrm{C}$ overnight, placed in a desiccator until it reached constant weight. To calculate the percentage of cellulose and hemicelluloses present in the liquor, we considered the amount of recovered biomass (br), deducting the masses of sodium hydroxide and sulfuric acid used for $\mathrm{pH}$ correction, according to Equation (6):

Recovered biomass $=M T_{\text {liquor }}-M_{h}-M_{a c}$

where $M T_{\text {liquor }}$ is total mass of liquor $(\mathrm{g}) ; M_{h}$ is mass of sodium hydroxide $(\mathrm{g}) ; M_{a c}$ is a mass of sulfuric acid used to correct $\mathrm{pH}(\mathrm{g})$. With the determination of sugars, the composition of macromolecules was obtained according to the respective conversion factors, from Equation (7):

$\%$ Macromolecule $=\sum \frac{\left(\frac{0.005174 \times(\mathrm{Cm} \times f) \times V T}{5} \times \frac{V r}{V L}\right)}{b r \times 100}$

where $\mathrm{Cm}$ is sugar concentration (glucose, xylose, etc.) $\left(\mathrm{gL}^{-1}\right) ; f$ is sugar conversion factor into cellulose or hemicelluloses; $V T$ is total volume used in $\mathrm{pH}$ correction (volume of liquor + volume of acid) $(\mathrm{mL})$; $V r$ is total volume recovered in the filtration of the pretreated cake $(\mathrm{mL}) ; V L$ is volume of liquor used to correct $\mathrm{pH}(\mathrm{mL}) ; b r$ is recovered biomass $(\mathrm{g})$.

\section{Enzymatic hydrolysis of pretreated material}

Enzymatic hydrolysis was carried out for each pretreatment at $50{ }^{\circ} \mathrm{C}$ and $\mathrm{pH} 4.8$ - the optimal conditions for the enzyme - for glucose quantification. The enzymatic hydrolysis used commercially relevant 
doses of Novozymes Cellic ${ }^{\circ} \mathrm{CTec} 3$ (15 FPU/g biomass) at $4 \%(\mathrm{w} / \mathrm{v})$ solids loading. After drying and grinding the pretreated residue, $0.04 \mathrm{~g}$ of the cake (dry mass) from each test was weighed and placed in microtubes of $2 \mathrm{~mL}$, along with the enzyme, and citrate buffer $(0.1 \mathrm{M})$ was added to complete the total volume of $1 \mathrm{~mL}$; they were then placed on plates of 24 wells. The plates were shaker incubated with rotation maintained at $200 \mathrm{rpm}$ and $50{ }^{\circ} \mathrm{C}$. After 48 hours, the reaction liquid was placed in microtubes, centrifuged at $14000 \mathrm{rpm}$ for 10 minutes and the supernatant was reserved for analysis. This procedure did not affect the hydrolysis performance, because in this stirring system, the microtube was positioned inside a $24-$ well microplate well and the tapping of the tube on the wall of the well also created turbulence inside the tube, which facilitated the enzyme access to the substrate. In addition, biomass pretreated by an alkaline process is very easy to hydrolyze, because it contains swollen cellulose, with a relatively high degree of purity. Some publications using this system can be pointed out. ${ }^{18,19}$ The calculation of the \% conversion of cellulose in glucose was made according to the following Equation (8):

$$
\text { Conversion }=\frac{\text { Theoretical concentration of glucose in the material }}{\text { Glucose concentration observed in hydrolyzate }} \times 100
$$

Table 1

Factorial planning levels for alkaline pretreatment

\begin{tabular}{lccc}
\hline \multirow{2}{*}{ Factors } & \multicolumn{3}{c}{ Levels } \\
\cline { 2 - 4 } & -1 & 0 & 1 \\
\hline $\mathrm{NaOH}(\% \mathrm{w} / \mathrm{v})$ & 4 & 6 & 8 \\
Time (min) & 30 & 60 & 90 \\
\hline
\end{tabular}

\section{Experimental planning}

A factorial design $\left(2^{2}\right)$ with 3 experiments at the central point was carried out. The factors were: treatment time (t) and concentration of sodium hydroxide $(\% \mathrm{w} / \mathrm{v})$. Their effect on the response variables, such as the losses of cellulose, hemicelluloses and percentage delignification was determined. The planning levels are shown in Table 1 .

$30 \mathrm{~g}$ of dry bagasse was weighed and added to 4$8 \% \mathrm{w} / \mathrm{v}$ sodium hydroxide solution, in a ratio of $1: 10$ ( $\mathrm{g}$ of dry material/mL sodium hydroxide solution), thus using an alkali level between 0.4-0.8 g NaOH/g of material. Other solid-liquid relationships have not been studied, as there are already several studies in the literature showing that for alkaline pretreatments the ratio of solid:liquid equal to $1: 10$, turns out to be one of the most appropriate. ${ }^{10-12,20,21}$ The material was homogenized and autoclaved at $121{ }^{\circ} \mathrm{C}$ for each planning time. After completion of the pretreatment, the bagasse was filtered. The black liquor obtained after filtration was measured for its weight and volume. The solid fraction was washed thoroughly until a neutral $\mathrm{pH}$ was reached. The raw pulp from BSG was dried at room temperature and subsequently evaluated for the process mass yield (Eq. 9).

$$
R=\frac{m_{\text {final }}}{\left(m_{\text {initial }}\right)} \times 100
$$

where $m_{\text {initial }}$ : initial dry mass of the lignocellulosic material $(\mathrm{g}) ; m_{\text {final }}$ : final dry mass of the lignocellulosic material $(\mathrm{g}) ; R$ : mass yield of the process.

The loss of the macromolecular component (cellulose, hemicelluloses and lignin) was calculated by the following Equation (10):

$P=\frac{\left(M_{i} \times Y_{i}\right)-\left(M_{f} \times Y_{f}\right)}{(M i x Y i)} \times 100$ where $P$ is the loss of the macromolecular component $(\%) ; M_{i}$ is the initial mass of lignocellulosic material; $Y_{i}$ is the $\%$ content of the macromolecular component in the natural lignocellulosic material; $Y_{f}$ is the $\%$ content of the macromolecular component in the pretreated lignocellulosic material; $M_{f}$ is final dry mass of lignocellulosic material $(\mathrm{g})$.

\section{RESULTS AND DISCUSSION Characterization of in natura brewer's spent grain}

Table 2 shows the results of the $\mathrm{B} 1$ and $\mathrm{B} 2$ bagasse characterization in the presence and absence of extractives.

In order to evaluate the influence of the extractives (non-structural material from biomass) on the characterization of in-natura BSG from the two breweries, a step of removing the extractives was carried out, this allowed a comparative characterization of the material before and after removing the extractives. Table 2 shows that in natura biomasses contain a considerable amount of extractives, which are compounds that are not covalently linked to the biomass structure, such as sucrose, nitrates/nitrites, proteins, chlorophyll and greases/waxes. These extractives affect the quantification of the structural components of biomass, for this reason, this procedure must be performed before the determination of structural carbohydrates (cellulose, hemicelluloses) and lignin in the biomass. All the calculations of the percentage of the individual components were 
made in relation to BSG with extractives (on dry basis).

In the case of material B1, about $17 \%$ of extractives interfere in the characterization of biomass, underestimating the percentages of cellulose and hemicelluloses, and overestimating the values of lignin and protein. As for bagasse B2, the high content of extractives (almost 21\%) leads to an underestimated value of hemicelluloses and overestimated protein, without interfering with the values for the other components. This difference confirms that the removal of extractive components is a relevant factor, justifying the realization of the step of extractives removal before the characterization procedures, as established by Sluiter et al. ${ }^{15}$

The differences presented between the two materials are expected, so that the centesimal composition of the BSG is a function of barley variety, harvest time, cereals and conditions used in malting, a technological process employed in the brewery, as well as of the quality and type of added adjuncts to the fermentation process. ${ }^{5,22}$ Thus, it can be seen that approximately $30 \%$ of the composition on a dry basis represents a very important fraction that should be accessible for the enzymatic hydrolysis process.

\section{Pretreatment evaluation of brewer's spent grain with sodium hydroxide}

With the aim to increase the economic viability of the process in general, the pretreatments were conducted on the in natura bagasse, without the step of extractives removal, to allow comparison between the components of in natura and pretreated BSG. It is necessary to use the corrected composition by the pretreatment mass yield, multiplying each component by the yield value. The percentages of cellulose, hemicelluloses, total lignin, proteins, ashes, and the pretreatment yields are shown in Table 3 (the characterizations were performed in triplicate).

Table 2

Characterization of B1 and B2 in natura brewer's spent grain, before and after removal of extractives

\begin{tabular}{lcccc}
\hline \multirow{2}{*}{ Component } & \multicolumn{2}{c}{ Material } \\
\cline { 2 - 5 } & \multicolumn{2}{c}{ Imperial (B1) } & \multicolumn{2}{c}{ Colombina (B2) } \\
\cline { 2 - 5 } & Before extraction & After extraction & Before extraction & After extraction \\
\hline Cellulose* (\%) & $8.59 \pm 2.67$ & $12.00 \pm 0.38$ & $14.47 \pm 2.32$ & $13.79 \pm 0.43$ \\
Hemicellulose* $(\%)$ & $5.18 \pm 1.54$ & $16.88 \pm 0.48$ & $4.38 \pm 0.96$ & $15.32 \pm 0.57$ \\
Lignin* (\%) & $35.82 \pm 0.622$ & $28.01 \pm 0.97$ & $29.57 \pm 1.95$ & $26.11 \pm 1.20$ \\
Proteins* (\%) & $32.21 \pm 1.031$ & $22.17 \pm 0.73$ & $30.13 \pm 0.17$ & $20.24 \pm 1.43$ \\
Extractives*(\%) & - & $17.18 \pm 0.42$ & - & $20.88 \pm 0.67$ \\
Ashes* (\%) & $1.67 \pm 0.06$ & $2.18 \pm 0.09$ & $0.99 \pm 0.10$ & $2.05 \pm 0.21$ \\
Total* (\%) & $83.47 \pm 5.92$ & $98.42 \pm 3.08$ & $79.54 \pm 5.50$ & $98.39 \pm 4.51$ \\
\hline
\end{tabular}

* \% on dry initial BSG basis; \pm standard deviation

According to the data listed in Table 3 , it is important to note that, for the same pretreatment conditions, there is a considerable variation in the cellulose obtained, indicating the heterogeneity of $\mathrm{BSG}$, even though it is from the same batch and brewery. The beer production process involves the addition of other components, and part of the barley malt can be replaced by adjuncts (rice, wheat, rye, corn, oats and sorghum, all wholegrain, in flakes or the starchy part) and by carbohydrates of vegetable origin, giving rise to varied flavors and aromas of beers. ${ }^{3}$

It is possible to observe that, after the pretreatments, both types of BSG showed a decrease in the levels of hemicelluloses and lignin (see Tables 2 and 3). This occurs in an alkaline medium due to the solubilization of these components, while there is almost no solubilization of cellulose. ${ }^{23-26}$ At the same time, as expected, protein levels were drastically reduced after the pretreatments, since proteins are degraded by both the action of sodium hydroxide and the action of temperature. As for the cellulose content, after the pretreatments, for both BSG in most cases, there was a loss of cellulose when compared to in natura BSG. For materials B1 and B2, the highest percentage of cellulose was obtained under the conditions of the central pretreatment point, that is, using $6 \% \mathrm{NaOH}$ and a reaction time of 60 minutes. The results of cellulose loss, hemicelluloses removal and lignin 
removal from the pretreated $\mathrm{B} 1$ and $\mathrm{B} 2$ materials

were calculated and presented in Table 4.

Table 3

Chemical characterization of $\mathrm{NaOH}$ pretreated materials at $121{ }^{\circ} \mathrm{C}, 1 \mathrm{~atm}$ and solid-to-liquid ratio of $1: 10(\mathrm{w} / \mathrm{v})$, corrected by the mass yield factor, i.e. expressed as \% on dry BSG basis

\begin{tabular}{|c|c|c|c|c|c|c|c|}
\hline \multirow{3}{*}{ Component } & \multicolumn{7}{|c|}{ Pretreatment conditions } \\
\hline & \multicolumn{2}{|c|}{$\mathrm{NaOH}(4 \%)$} & \multicolumn{3}{|c|}{$\mathrm{NaOH}(6 \%)$} & \multicolumn{2}{|c|}{$\mathrm{NaOH}(8 \%)$} \\
\hline & $30 \mathrm{~min}$ & $90 \mathrm{~min}$ & $60 \mathrm{~min}$ & $60 \mathrm{~min}$ & $60 \mathrm{~min}$ & $30 \mathrm{~min}$ & $90 \mathrm{~min}$ \\
\hline \multirow{4}{*}{$\begin{array}{l}\text { Cellulose } \\
(\%)\end{array}$} & $6.36 \pm$ & $3.40 \pm$ & $7.53 \pm$ & $8.31 \pm$ & $8.13 \pm$ & $4.87 \pm$ & $4.89 \pm$ \\
\hline & $2.04^{\mathrm{a}}$ & $0.94^{\mathrm{a}}$ & $1.64^{\mathrm{a}}$ & $2.06^{\mathrm{a}}$ & $1.40^{\mathrm{a}}$ & $1.35^{\mathrm{a}}$ & $1.21^{\mathrm{a}}$ \\
\hline & $7.36 \pm$ & $6.84 \pm$ & $6.15 \pm$ & $6.20 \pm$ & $7.99 \pm$ & $7.16 \pm$ & $5.57 \pm$ \\
\hline & $0.40^{\mathrm{b}}$ & $0.70^{\mathrm{b}}$ & $0.40^{\mathrm{b}}$ & $0.20^{\mathrm{b}}$ & $0.38^{\mathrm{b}}$ & $0.37^{\mathrm{b}}$ & $0.35^{\mathrm{b}}$ \\
\hline \multirow{4}{*}{$\begin{array}{l}\text { Hemicelluloses } \\
(\%)\end{array}$} & $2.36 \pm$ & $1.01 \pm$ & $1.30 \pm$ & $1.61 \pm$ & $1.78 \pm$ & $0.84 \pm$ & $0.66 \pm$ \\
\hline & $0.68^{\mathrm{a}}$ & $0.35^{\mathrm{a}}$ & $0.54^{\mathrm{a}}$ & $0.45^{\mathrm{a}}$ & $0.38^{\mathrm{a}}$ & $0.33^{\mathrm{a}}$ & $0.16^{\mathrm{a}}$ \\
\hline & $1.27 \pm$ & $0.67 \pm$ & $0.63 \pm$ & $0.63 \pm$ & $1.86 \pm$ & $0.69 \pm$ & $0.55 \pm$ \\
\hline & $0.05 b$ & $0.21^{\mathrm{b}}$ & $0.06^{\mathrm{b}}$ & $0.03^{\mathrm{b}}$ & $0.07^{\mathrm{b}}$ & $0.01^{\mathrm{b}}$ & $0.07^{\mathrm{b}}$ \\
\hline \multirow{4}{*}{$\begin{array}{l}\text { Lignin } \\
(\%)\end{array}$} & $2.75 \pm$ & $2.17 \pm$ & $2.35 \pm$ & $2.22 \pm$ & $3.49 \pm$ & $2.16 \pm$ & $1.61 \pm$ \\
\hline & $0.58^{\mathrm{a}}$ & $0.57^{\mathrm{a}}$ & $0.52^{\mathrm{a}}$ & $0.47^{\mathrm{a}}$ & $0.49^{\mathrm{a}}$ & $0.84^{\mathrm{a}}$ & $0.41^{\mathrm{a}}$ \\
\hline & $1.79 \pm$ & $1.96 \pm$ & $1.70 \pm$ & $1.55 \pm$ & $1.79 \pm$ & $1.56 \pm$ & $1.35 \pm$ \\
\hline & $0.13^{\mathrm{b}}$ & $0.57^{\mathrm{b}}$ & $0.06^{\mathrm{b}}$ & $0.16^{\mathrm{b}}$ & $0.14^{\mathrm{b}}$ & $0.30^{\mathrm{b}}$ & $0.10^{\mathrm{b}}$ \\
\hline \multirow{4}{*}{$\begin{array}{l}\text { Proteins } \\
(\%)\end{array}$} & $0.87 \pm$ & $0.39 \pm$ & $0.60 \pm$ & $0.49 \pm$ & $1.12 \pm$ & $0.52 \pm$ & $0.36 \pm$ \\
\hline & $0.17^{\mathrm{a}}$ & $0.11^{\mathrm{a}}$ & $0.15^{\mathrm{a}}$ & $0.08^{\mathrm{a}}$ & $0.18^{\mathrm{a}}$ & $0.17^{\mathrm{a}}$ & $0.10^{\mathrm{a}}$ \\
\hline & $0.45 \pm$ & $0.42 \pm$ & $0.38 \pm$ & $0.42 \pm$ & $0.39 \pm$ & $0.46 \pm$ & $0.41 \pm$ \\
\hline & $0.03^{\mathrm{b}}$ & $0.03^{\mathrm{b}}$ & $0.05^{\mathrm{b}}$ & $0.03^{\mathrm{b}}$ & $0.05^{\mathrm{b}}$ & $0.04^{\mathrm{b}}$ & $0.02^{\mathrm{b}}$ \\
\hline \multirow{4}{*}{$\begin{array}{l}\text { Ashes } \\
(\%)\end{array}$} & $0.19 \pm$ & $0.15 \pm$ & $0.23 \pm$ & $0.24 \pm$ & $0.15 \pm$ & $0.22 \pm$ & $0.16 \pm$ \\
\hline & $0.05^{\mathrm{a}}$ & $0.12^{\mathrm{a}}$ & $0.08^{\mathrm{a}}$ & $0.08^{\mathrm{a}}$ & $0.06^{\mathrm{a}}$ & $0.16^{\mathrm{a}}$ & $0.08^{\mathrm{a}}$ \\
\hline & $0.01 \pm$ & $0.09 \pm$ & $0.02 \pm$ & $0.02 \pm$ & $0.08 \pm$ & $0.04 \pm$ & $0.02 \pm$ \\
\hline & $0.01^{\mathrm{b}}$ & $0.02^{\mathrm{b}}$ & $0.01^{\mathrm{b}}$ & $0.01^{\mathrm{b}}$ & $0.02^{\mathrm{b}}$ & $0.02^{\mathrm{b}}$ & $0.02^{\mathrm{b}}$ \\
\hline \multirow{2}{*}{$\begin{array}{l}\text { Yield } \\
(\%)\end{array}$} & $16.40^{\mathrm{a}}$ & $12.90^{\mathrm{a}}$ & $17.48^{\mathrm{a}}$ & $16.56^{\mathrm{a}}$ & $21.95^{\mathrm{a}}$ & $13.06^{\mathrm{a}}$ & $12.15^{\mathrm{a}}$ \\
\hline & $11.50^{\mathrm{b}}$ & $11.92^{\mathrm{b}}$ & $11.49^{\mathrm{b}}$ & $11.93^{\mathrm{b}}$ & $12.22^{\mathrm{b}}$ & $11.58^{\mathrm{b}}$ & $10.61^{\mathrm{b}}$ \\
\hline
\end{tabular}

${ }^{\mathrm{a}} \mathrm{Brewer}$ 's spent grain B1; ${ }^{\mathrm{b}}$ Brewer's spent grain B $\left.\overline{2 ;(38.81 \%} * 0.1640=6.36\right)$

From the data obtained in Table 4, it can be seen that, in the experiments with BSG B1, the loss of cellulose varied in the range of 3.2-60.4\%, depending on the conditions, whereas in the experiments with the material $\mathrm{B} 2$, this range was smaller, of $7.0-35.2 \%$. A possible explanation for this difference could be in the origin of the cereals used for BSG B1, since the chemical composition of BSG can vary according to the variety of barley, the time of harvest, the conditions of malting and grinding, the adjuncts added, and the quality and type of adjuvants added to the brewing process. ${ }^{27,28}$

Aliyu and Bala $^{29}$ showed variations in chemical composition for different BSGs from different continents. The researchers attributed the variation in the percentage composition of cellulose, hemicelluloses and lignin to the variety of grains used during the process and the characteristics mentioned above. In addition, because of the competitiveness on the beer market, breweries are seeking to reduce the cost of beer production. To achieve these goals, they increasingly replace malt with several cheaper adjuncts. It is estimated that 85 to $90 \%$ of the beer produced worldwide is obtained with the addition of adjuncts now. ${ }^{30}$ Most of the starch present in the components used for the production of beer is removed during the malting, extraction and fermentation. However, an amount of residual starch, at least $5 \%$, can remain within $\mathrm{BSG}^{31}$ In this study, residual starch may have interfered in the analysis of cellulose loss. The removal of this starch during the alkaline pretreatment may have led to overestimating cellulose loss in this process. Regarding the percentage of hemicellulose removal, the two biomasses (B1 and $\mathrm{B} 2$ ) presented similar ranges, with variations around 30\% in the studied ranges of operation and a removal percentage higher than $50 \%$. When analyzing lignin, this response variable showed removal values greater than $90 \%$ for both materials, emphasizing that, in the case of material B2, the removal values were higher when compared to those obtained in material B1 for all evaluated conditions. These results are similar to 
those obtained by Cheng et al. ${ }^{32}$ who obtained a high degree of delignification with less degradation of hemicelluloses, using an alkaline pretreatment. These results are associated with the main effect of the pretreatment with sodium hydroxide - in lignocellulosic materials, delignification occurs because of the breaking of the ester bonds that crosslink lignin and xylan, thus increasing the porosity of the biomass. ${ }^{33,34}$ In addition, in the alkaline pretreatment, sodium hydroxide is dissociated into the hydroxide ion $(\mathrm{OH}-)$ and the sodium ion $(\mathrm{Na}+)$, and, as the concentration of the hydroxide ion increases, the rate of the hydrolysis reaction increases proportionally.

Table 4

Chemical characterization of $\mathrm{NaOH}$ pretreated materials at $121{ }^{\circ} \mathrm{C}, 1$ atm and solid-to-liquid ratio of $1: 10(\mathrm{~m} / \mathrm{v})$, corrected by the mass yield factor

\begin{tabular}{lcccccc}
\hline & \multicolumn{3}{c}{ BSG Imperial (B1) } & \multicolumn{3}{c}{ BSG Colombina (B2) } \\
\hline $\begin{array}{l}\text { Pretreatment } \\
\text { conditions }\end{array}$ & $\begin{array}{c}\text { Cellulose } \\
\text { loss } \\
(\%)\end{array}$ & $\begin{array}{c}\text { Hemicellulose } \\
\text { removal } \\
(\%)\end{array}$ & $\begin{array}{c}\text { Lignin } \\
\text { removal } \\
(\%)\end{array}$ & $\begin{array}{c}\text { Cellulose } \\
\text { loss } \\
(\%)\end{array}$ & $\begin{array}{c}\text { Hemicellulose } \\
\text { removal } \\
(\%)\end{array}$ & $\begin{array}{c}\text { Lignin } \\
\text { removal } \\
(\%)\end{array}$ \\
\hline $\begin{array}{l}\text { NaOH 4\%, } \\
30 \text { min }\end{array}$ & 25.9 & 54.4 & 92.3 & 14.3 & 75.6 & 95.0 \\
\hline $\begin{array}{l}\mathrm{NaOH} 8 \%, \\
30 \mathrm{~min}\end{array}$ & 43.3 & 83.7 & 94.0 & 16.7 & 86.6 & 95.7 \\
\hline $\begin{array}{l}\mathrm{NaOH} 4 \%, \\
90 \mathrm{~min}\end{array}$ & 60.4 & 80.5 & 93.9 & 20.4 & 87.0 & 94.5 \\
\hline $\begin{array}{l}\mathrm{NaOH} 8 \%, \\
90 \mathrm{~min}\end{array}$ & 43.1 & 87.3 & 95.5 & 35.2 & 89.5 & 96.2 \\
\hline $\begin{array}{l}\mathrm{NaOH} 6 \%, \\
60 \mathrm{~min}\end{array}$ & 12.3 & 74.9 & 93.4 & 28.4 & 87.9 & 95.3 \\
\hline $\begin{array}{l}\mathrm{NaOH} 6 \%, \\
60 \mathrm{~min}\end{array}$ & 3.2 & 68.8 & 93.8 & 27.9 & 87.8 & 94.9 \\
\hline $\begin{array}{l}\mathrm{NaOH} 6 \%, \\
60 \mathrm{~min}\end{array}$ & 5.4 & 65.7 & 90.3 & 7.0 & 63.6 & 95.0 \\
\hline
\end{tabular}

Table 5

Analysis of the main effects, interactions and regression coefficients for lignin removal after alkaline pretreatment

\begin{tabular}{lcccc}
\hline Material (BSG) & \multicolumn{2}{c}{ B1 } & \multicolumn{2}{c}{ B2 } \\
\hline Factor & Coefficient & p-value & Coefficient & p-value \\
\hline Average & 92.49681 & 0.000147 & 95.06528 & 0.000001 \\
Time (1) & 1.57880 & 0.501773 & 0.06190 & 0.752337 \\
NaOH (2) & 1.60932 & 0.494586 & 1.18124 & 0.020372 \\
1 L by 2 L & -0.02544 & 0.990741 & 0.52744 & 0.091201 \\
\hline
\end{tabular}

$1 \mathrm{~L}$ by $2 \mathrm{~L}$ : is the time- $\mathrm{NaOH}$ linear interaction coefficient

This justifies the higher rates of removal of lignin under the most severe pretreatment conditions combining $8 \% \mathrm{NaOH}$ and $90 \mathrm{~min}$ of reaction time. This reaction occurs with the effective attack of sodium hydroxide on the connection between lignin and hemicelluloses. In lignincarbohydrate (LC) complexes, in particular, in addition to cleaving the ether and ester bonds in the LC structure, sodium hydroxide is also effective in cleaving the ester and carbon-carbon (C-C) bonds in lignin (ferulic acid) molecules.35
For these reasons, the pretreatment with $\mathrm{NaOH}$ is considered to be one of the most effective, among many other proposed processes, since it liberates hemicelluloses and lignin from cellulose, avoiding fragmentation of the hemicelluloses, which turns out to be of great interest for the further use of this fraction.36,37

\section{Factorial design of experiments}

Table 5 shows the scaled regression coefficients for the regression model of \% lignin 


\section{CARLA LOBO GOMES et al.}

removal after the sodium hydroxide pretreatment. The statistical analysis was performed using the Statistica v.7.0 software and the confidence level was $90 \%$. Significant effects have a p-value $<0.1$.

The data in the table show that, for a $90 \%$ confidence level, the pretreatment time is not significant for lignin removal for either material
(B1 and B2). However, in material B2, the concentration of $\mathrm{NaOH}$ and the time- $\mathrm{NaOH}$ interaction are significant, in particular, the concentration of $\mathrm{NaOH}$ turns out to be the most important factor, since it presents a p-value lower than that obtained for the interaction time- $\mathrm{NaOH}$.
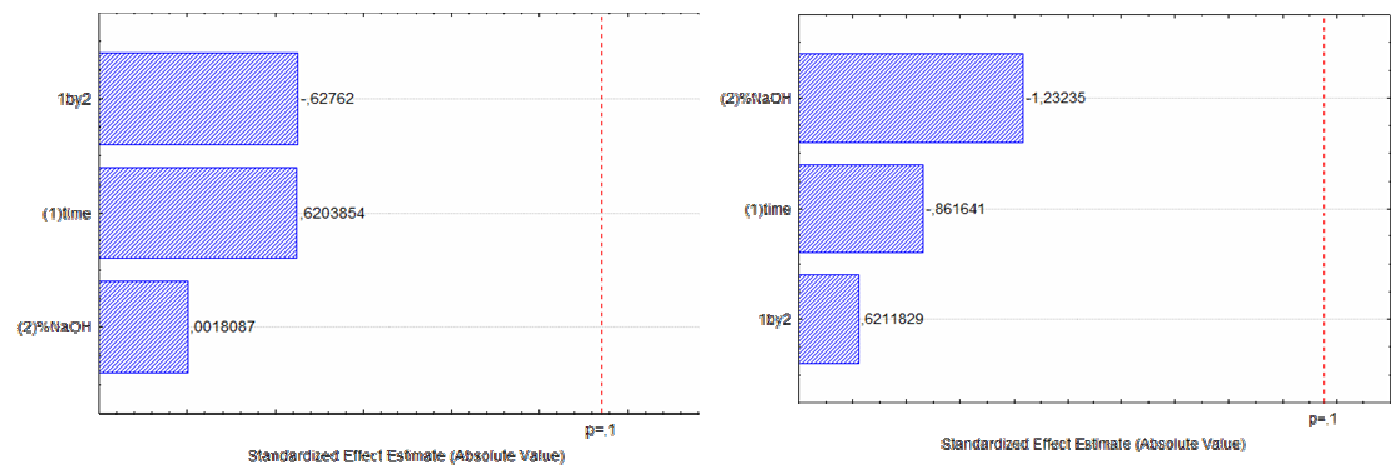

Figure 1: Pareto chart of standardized effects; variable: cellulose loss; (a) B1 material, (b) B2 material
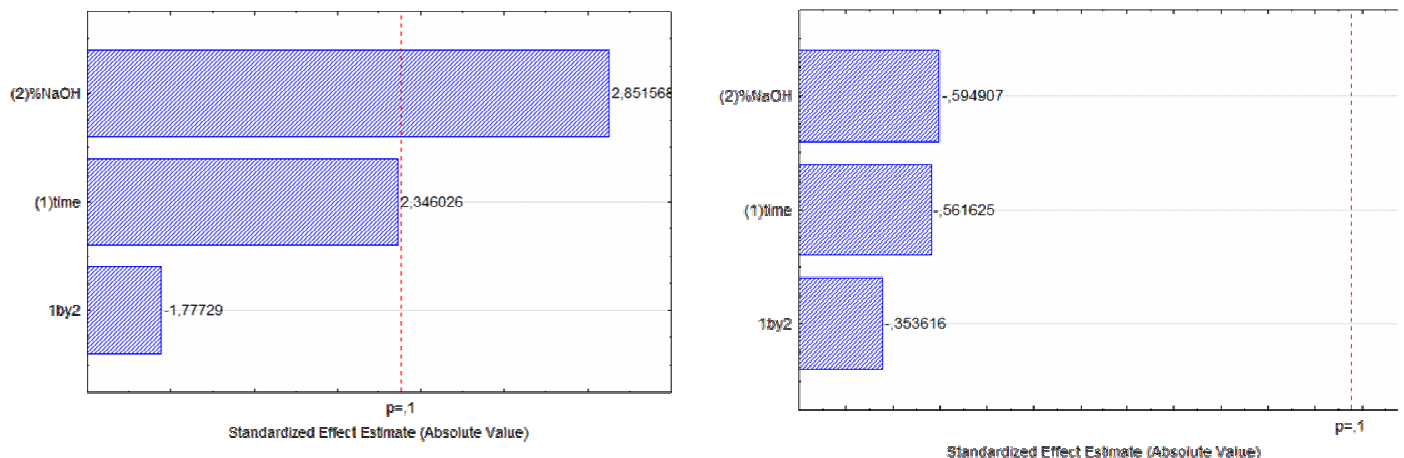

Figure 2: Pareto chart of standardized effects; variable: hemicellulose removal, (a) B1 material, (b) B2 material

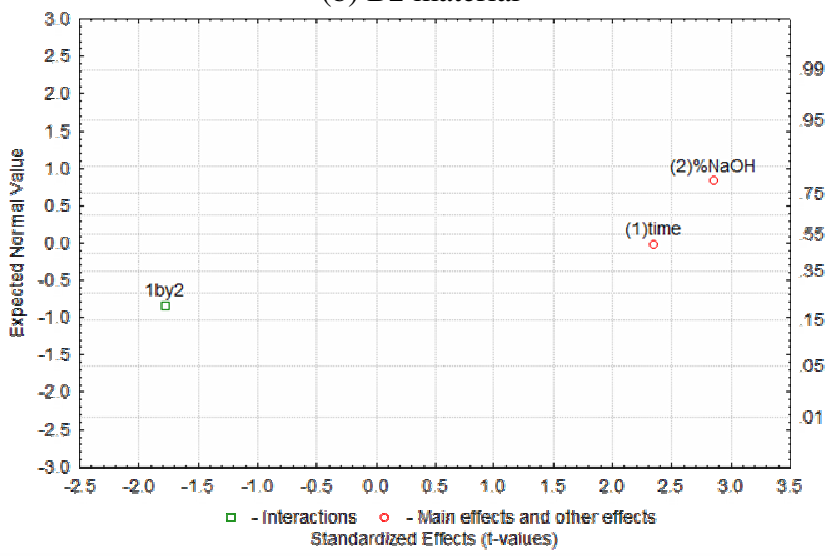

Figure 3: Normal probability plot of effects; variable: hemicellulose removal of B1 material 
a)
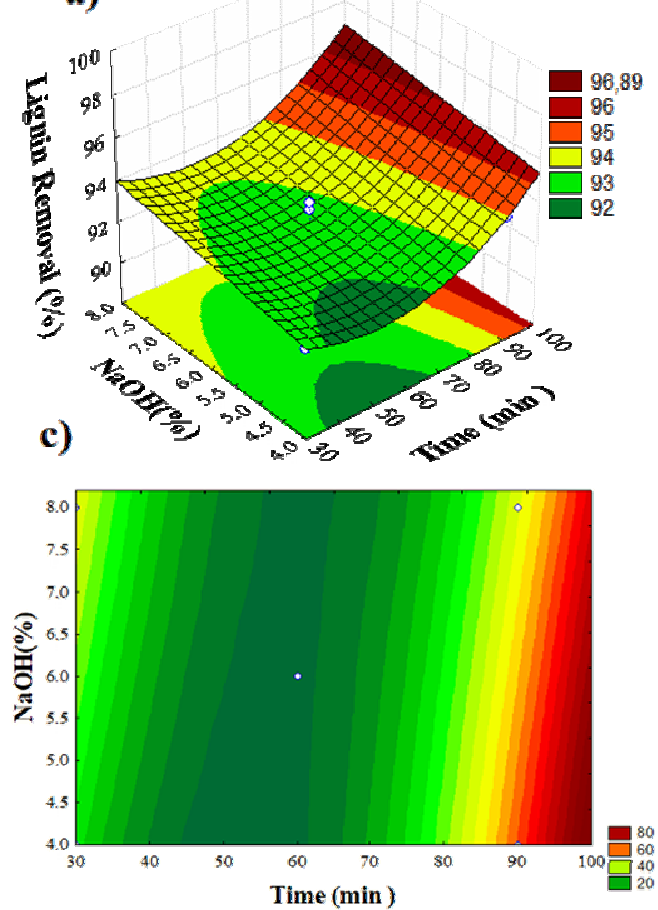

b)

d)
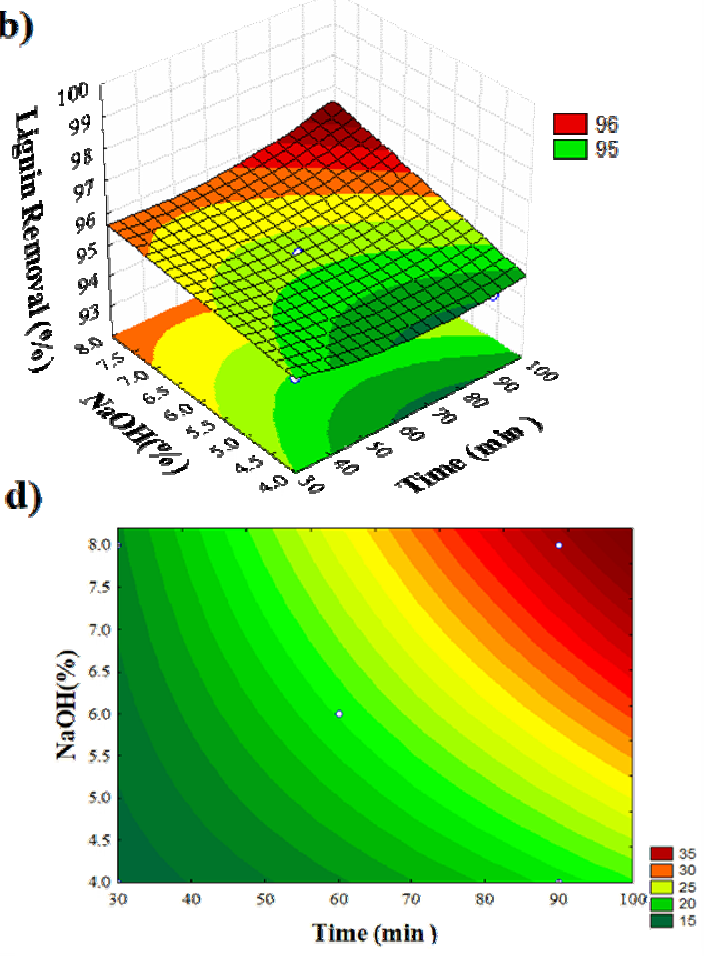

Figure 4: Response surface plots for \% lignin removal as a function of $\mathrm{NaOH}$ concentration and time; a) material $\mathrm{B} 1 ; \mathrm{b}$ ) material B2; c) \% loss cellulose BSG B1; d) \% loss cellulose BSG B2

Also, an analysis of the coefficient values for material B2 allows identifying that the effect of $\mathrm{NaOH}$ concentration, like the time- $\mathrm{NaOH}$ interaction, contributes positively to the increase in the lignin removal from the material, which, in this case, is suitable, since the main objective of delignification is to try to remove the largest amount of lignin, but without a significant increase in the loss of cellulose present in the material, since greater content of cellulose in BSG will lead to obtaining a higher concentration of glucose in the hydrolysis process. ${ }^{38}$ In relation to the response variable \% loss cellulose, there is no significant influence on the variables tested in the evaluated intervals (Fig. 1). On the other hand, for the response variable \% hemicellulose removal, in the case of material $\mathrm{B} 1$, the factor $\% \mathrm{NaOH}$ turns out to be significant, with a confidence interval of $90 \%$ (Fig. 2). The sodium hydroxide concentration factor (2) has a positive standardized effect. In other words, when the $\mathrm{NaOH}$ concentration changes from a low to a high level of the factor, the response increases (Fig. 3).
The response surface of \% lignin removal versus time and sodium hydroxide concentration for two materials is shown in Figure 4. The results obtained in this factorial design analysis allow establishing an initial operating range for the delignification of brewer's spent grain. In Figure 4 ( $a$ and b), it can be seen that, for high concentrations of sodium hydroxide and longer times of reaction, lignin solubilization is the highest, indicating a trend towards an effective removal of this component from BSG. However, an analysis of the amount of cellulose present in the material at the end of the process for these more severe conditions shows that there is a greater loss of this component in the material, consequently, an increase in the conditions of time and sodium hydroxide concentration to try to eliminate a greater amount of lignin can cause a greater loss of cellulose. Therefore, one should find a balance between delignification and polysaccharides losses. 


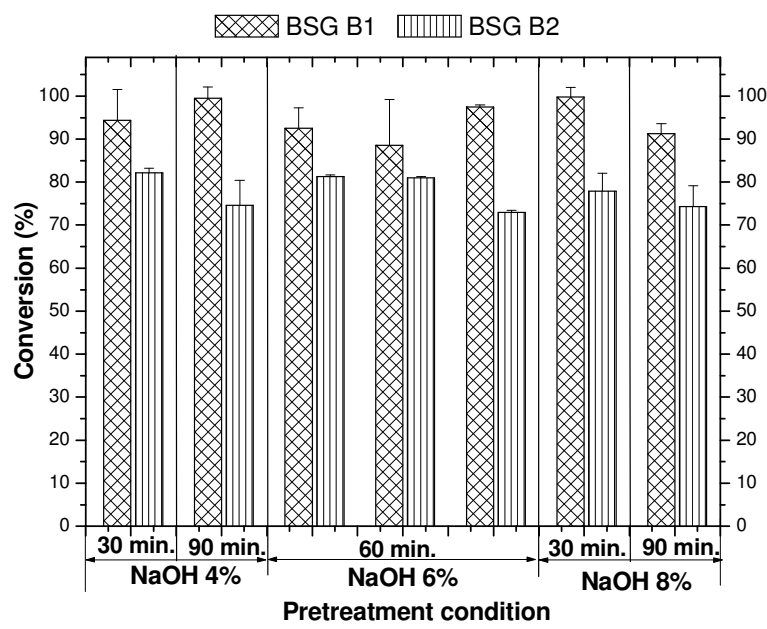

Figure 5: Cellulose to glucose conversion from enzymatic hydrolysis of brewer's spent grain B2

\section{Enzymatic hydrolysis}

Pretreated materials B1 and B2 were subjected to enzymatic hydrolysis tests to evaluate the effect of pretreatment with sodium hydroxide on the conversion of cellulose to glucose. The results obtained from the triplicate hydrolysis experiments are shown in Figure 5.

This resulted in cellulose-to-glucose conversions greater than $70 \%$ for all the pretreatments. It is worth noting that the greatest conversions obtained were those in which the B1 material was used, although this material presents, on average, a 5\% higher amount of lignin present in the lignocellulosic complex. These variations in material conversions turn out to be something unexpected, since these combinations had not stood out in the analysis of the pretreated material. Otherwise said, among the factors studied (loss of cellulose, removal of hemicelluloses and lignin) and pointed out as the main influencers of the enzymatic hydrolysis stage, it is the most severe conditions that have shown greater significance. Kim et al $^{35}$ stated that it is not just the gross amount of lignin in the biomass that controls enzymatic hydrolysis. This explains the results found in the present research: the location of the lignin in the biomass, the surface area of the lignin and the properties and condition of the lignin surface also play significant roles. An example is the nonproductive binding of the enzyme to lignin, which makes the enzyme irreversibly inactive. This binding is related to the surface area of lignin (not its gross quantity) and its location, as well as its surface properties, which affect its affinity with the protein. ${ }^{39}$ We believe that, in addition to the effects of the remaining lignin on enzymatic hydrolysis, extractives such as proteins, which were not completely removed after the pretreatment, could affect this process. This hypothesis could not be confirmed in this study because the extractives in the pretreated material were not quantified.

\section{CONCLUSION}

The chemical characterization of brewer's spent grain is an extremely important step, being used as a comparative parameter between the studied bagasse and the pretreatment conditions used. The removal of extractive components is a relevant factor to obtain a composition more consistent with reality, thus justifying the realization of the extractives removal step before the characterization procedures. After the alkaline pretreatment with $\mathrm{NaOH}, \mathrm{B} 1$ presented lower cellulose loss for the combination of $6 \% \mathrm{NaOH}$ and $60 \mathrm{~min}$, on the other hand, the highest hemicellulose and lignin removal rates occurred under the most severe pretreatment conditions: $8 \% \mathrm{NaOH}$ and 90 min. Meanwhile, for material B2, the lowest cellulose losses occurred under the least severe conditions of the pretreatment: $4 \%$ $\mathrm{NaOH}$ and $30 \mathrm{~min}$. These differences may be associated with the properties of the fiber structure, the type of cellulose present in the material (low/high crystallinity) and the surface composition in terms of cellulose and lignin, confirming the influence of the material on the pretreatment process. In the case of lignin and hemicellulose removal, higher values were 
achieved with higher $\mathrm{NaOH}$ concentration for both materials, with removal percentages greater than $50 \%$ and $90 \%$, respectively. These results show the efficiency of the alkaline pretreatment, even under the less severe conditions evaluated in this study. Also, its industrial application must be considered. Finally, with regard to the production of glucose in enzymatic hydrolysis, it was found that greater production of glucose will be a function of both the concentration of cellulose and the presence of lignin in the material. The latter plays a significant role, since not only its concentration, but also its location in the biomass will control the yield of enzymatic hydrolysis, and consequently, the maximum production of the product of interest, i.e. glucose.

ACKNOWLEDGEMENTS: This work was carried out with the support of the National Council for Scientific and Technological Development (CNPq - Process No 429195/20168 ) and the Coordination for the Improvement of Higher Education Personnel - Brazil (CAPES) Financing Code 001. The authors also thank Embrapa Agroenergia and FAPEG for their financial support.

\section{REFERENCES}

R. A. Curi, W. G. Venturini Filho, C. Ducatti and T. Nojimoto, Braz. J. Food Tech., 11, 4 (2008), http://bjft.ital.sp.gov.br/arquivos/artigos/v11n43707a.p $\mathrm{df}$

2 R. A. Curi, W. G. Venturini Filho and T. Nojimoto, Braz. J. Food Tech., 12, 2 (2009), http://doi.org/10.4260/BJFT2009800900004

J. F. Mega, E. Neves and C. J. Andrade, Citino, 1, 1 (2011)

4140 Years Barth Report, Hops 2016/2017, BarthHaas Group, 2017, http://www.johnihaas.com/wpcontent/uploads/2017/08/barthbericht20162017en.pdf

5 S. Mussatto and I. C. Roberto, J. Chem. Technol. Biotechnol., $\quad 81, \quad 3 \quad$ (2006), https://doi.org/10.1002/jctb.1374

6 P. Karagöz, I. V. Rocha, M. Özkan and I. Angelidaki, Bioresour. Technol., 104, 1 (2012), https://doi.org/10.1016/j.biortech.2011.10.075

Y. Sun and J. Cheng, Bioresour. Technol., 83, 1 (2002), https://doi.org/10.1016/S0960-8524(01)002127

8 L. V. Rao, J. K. Goli, J. Gentela and S. Koti, Bioresour. Technol., 213, 299 (2016), https://doi.org/10.1016/j.biortech.2016.04.092

9 S. Yang, Y. Zhang, W. Yue, W. Wang, Y. Y. Wang et al., Biotechnol. Biofuels, 9, 238 (2016), https://doi.org/10.1186/s13068-016-0656-1
10 Y. C. Park and J. S. Kim, Energy, 47, 1 (2012), https://doi.org/10.1016/j.energy.2012.08.010

11 C. E. A. Padilha, C. C. Nogueira, M. A. O. Filho, F. C. S. Júnior, C. F. Assis et al., J. Environ. Chem. Eng., 7, 6 (2019), https://doi.org/10.1016/j.jece.2019.103474 12 T. Yi, L. Qi, C. Wenqian and Z. Linguo, J. For. Eng., 5, 1 (2020), https://doi.org/10.13360/j.issn.20961359.201904030

13 C. Wyman, C. Cai and R. Charles, "Bioethanol from Lignocellulosic Biomass', Springer, 2017, https://doi.org/ 10.1007/978-1-4939-2493-6_521-3

14 A. Sluiter, R. Ruiz, C. Scarlata, J. Sluiter and D. Templeton, Determination of Extractives in Biomass, Columbus: Midwest Research Institute, 2008

15 A. Sluiter, R. Ruiz, C. Scarlata, J. Sluiter and D. Templeton, Determination of Structural Carbohydrates and Lignin in Biomass, Laboratory Analytical Procedures (LAP), National Renewable Energy Laboratory (NREL), revised version, 2012, Golden, Co.

16 D. C. Dayton and T. D. Foust, in "Analytical Methods for Biomass Characterization and Conversion", edited by D. Dayton and T. Foust, Elsevier, 2020, pp. 19-35, https://doi.org/10.1016/B978-0-12-815605-6.00002-0

17 R. Gouveia, R. T. Nascimento, A. M. Souto-Maior and G. J. M. Rocha, Quím. Nova, 32, 6 (2009), https://doi.org/10.1590/S0100-40422009000600026

18 C. Pengilly, M. García-Aparicio, J. P. J. Swart and J. F. Görgens, Biomass Conv. Bioref., (2020), https://doi.org/10.1007/s13399-020-00700-6

19 S. P. S. Chundawat, V. Balan and B. E. Dale, Biotechnol. Bioeng., 99, 6 (2008), https://doi.org/10.1002/bit.21805

20 V. M. Nascimento, A. M. P. W. Tardioli, R. C. Giordano, G. J. M. Rocha and R. L. C. Giordano, Bioethanol, 1, 2 (2016), https://doi.org/10.1515/bioeth2016-0008

21 T. H. Kim, F. Taylor and K. B. Hicks, Bioresour. Technol., $\quad 99, \quad 13 \quad$ (2008), https://doi.org/10.1016/j.biortech.2007.10.055

22 S. I. Mussatto, G. Dragone and I. C. Roberto, J. Cereal Sci., $\quad \mathbf{4 3}, \quad 2 \quad$ (2006), https://doi.org/10.1016/j.jcs.2005.06.001

23 A. Brandt, J. Gräsvik, J. P. Hallett and T. Welton, Green Chem., $15, \quad 550 \quad$ (2013), https://doi.org/10.1039/C2GC36364J

24 J. Fernández-Bolaños, B. Felizón, A. Heredia, R. Rodríguez, R. Guillén et al., Bioresour. Technol., 79, 1 (2001), https://doi.org/10.1016/S0960-8524(01)000153

25 I. Egüés, C. Sanchez, I. Mondragon and J. Labidi, Bioresour. Technol., 103, 1 (2012), https://doi.org/10.1016/j.biortech.2011.09.139

26 B. Xiao, X. F. Sun and R. C. Sun, Polym. Degrad. Stabil., 74, 2 (2001), https://doi.org/10.1016/S01413910(01)00163-X.

27 M. Santos, J. J. Jiménez, B. Bartolomé, C. GómezCordovés and M. J. D. Nozal, Food Chem., 80, 1 
(2003), https://doi.org/10.1016/S0308-8146(02)002297

28 J. A. Robertson, K. J. A. I'Anson, J. Treimo, C. B. Faulds, T. F. Brocklehurst et al., LWT-Food Sci. Technol., 43, 6 (2010), https://doi.org/10.1016/j.lwt.2010.01.019

29 S. Aliyu and M. Bala, Afr. J. Biotechnol., 10, 3 (2011), https://doi.org/10.5897/AJBx10.006

30 P. Bogdan and E. Kordialik-Bogacka, Trends Food

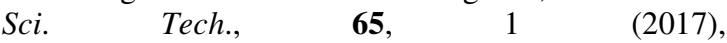
https://doi.org/10.1016/j.tifs.2017.05.001

31 K. Waldron, in "Handbook of Waste Management and Co-Product Recovery in Food Processing", edited by K. Waldron, Woodhead Publishing, 2009, pp. 680

K. K. Cheng, J. A. Zhang, W. X. Ping, J. P. Ge, Y. J. Zhou et al., Appl. Biochem. Biotech., 151, 1 (2008), https://doi.org/10.1007/s12010-008-8177-4

M. A. Kabel, F. Carvalheiro, G. Garrote, E. Avgerinos, E. Koukios et al., Carbohyd. Polym., 50,
$47 \quad$ (2002), https://doi.org/10.1016/S01448617(02)00045-0

34 J. Liu, P. Zhou, H. Liu, K. Wu, W. Xiao et al., Bioresour. Technol., 163, $390 \quad$ (2014), https://doi.org/10.1016/j.biortech.2014.04.106

35 S. M. Kim, B. S. Dien and V. Singh, Biotechnol. Biofuels, 9, 1 (2016), https://doi.org/10.1186/s13068016-0505-2

36 C. Somerville, H. Youngs, C. Taylor, S. C. Davis and P. S. Long, Science, 329, 5993 (2010), https://doi.org/10.1126/science.1189268

37 G. Garrote, H. Dominguez and J. C. Parajo, J. Food Eng., 52, 3 (2002), https://doi.org/10.1016/S02608774(01)00108-X

38 S. Wilkinson, K. A. Smart and D. J. Cook, Ind. Crop. $\quad$ Prod., $\quad$ 62, $219 \quad$ (2014), https://doi.org/10.1016/j.indcrop.2014.08.036

39 H. Zhang, L. Chen, J. Li, M. Lu and L. Han, Bioresour. Technol., 234, 23 (2017), https://doi.org/10.1016/j.biortech.2017.03.013 